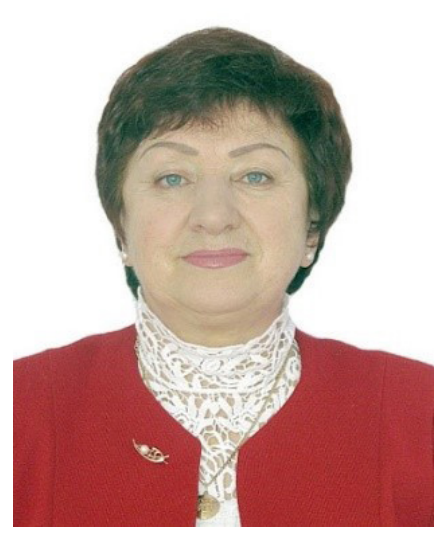

\author{
Ірина Мельничук,
}

доктор педагогічних наук, професор, завідувач кафедри педагогіки вищої школи та суспільних дисциплін, ДВНЗ «Тернопільський національний медичний університет імені І. Я. Горбачевського МОЗ України» (м. Тернопіль, Україна)

\section{Iryna Melnychuk,}

Doctor of Pedagogical Sciences, Professor, Head of the Department of Pedagogy of the Higher School and Social Disciplines Horbachevsky Ternopil State Medical University (Ternopil, Ukraine) ir.melnychuk@gmail.com ORCID ID 0000-0001-5527-0655

\title{
ІНТЕРАКТИВНІ ТЕХНОЛОГІЇ У ПІДГОТОВЦІ МАЙБУТНІХ ЛОГОПЕДІВ
}

Анотація. У статті узагальнено, що професійна підготовка майбутніх логопедів базується на опануванні студентами вмінь корегувати окремі складники порушеної мовленнєвої діяльності, що проявляються на ранніх етапах розвитку дитини. Актуалізовано використання інтерактивних технологій у підготовці майбутніх логопедів, які покликані опанувати вміння і навички організації оптимальної міжособистісної взаємодії з дітьми-логопатами.

Мета дослідження - розкрити можливості інтерактивних технологій у підготовці майбутніх логопедів до роботи за фахом та обґрунтувати методику використання інтерактивних вправ у роботі логопедів.

Установлено, що для корекційно-розвиткової роботи з дітьми з тяжкими порушеннями мовлення фахівці-логопеди можуть використовувати інтерактивні завдання. Майбутні логопеди в процесі професійної підготовки повинні апробувати такі інтерактивні вправи, які зможуть використовувати на заняттях з дітьми-логопатами. До таких завдань відносимо вправи для артикуляційної гімнастики. У статті наведено приклади окремих інтеракцій для навчання майбутніх логопедів роботи з дітьми-логопатами.

Доведено, що в професійній підготовці майбутніх логопедів необхідно зорієнтовувати студентів на розробку індивідуальної стратегії корекції порушень мовлення в розвитку кожної дитини. Задля цього доцільно спочатку апробувати на заняттях окремі інтерактивні вправи, які майбутні фахівці можуть адаптувати для цілеспрямованого розвитку мовленнєвої діяльності окремо взятої дитини, яка має індивідуальні специфічні мовленнєві порушення, пов'язані з психофізичними змінами в організмі, проблемами здоров'я, що ускладнюють соціальну адаптацію, навчання, розвиток дітей.

Отже, використання інтерактивних технологій у процесі професійної підготовки майбутніх логопедів має на меті розв'язання кількох важливих і взаємопов'язаних завдань: спрямованість професійної освіти на реальну практичну діяльність фахівця-логопеда, що сприятиме зростанню рівня його конкурентної спроможності на сучасному ринку праці; формування вмінь застосовувати особистісно зорієнтований підхід до дітей з різними логопедичними проблемами; розвиток креативності в розробці індивідуальних стратегій організації інтерактивної взаємодії з дітьмилогопатами шляхом адаптації апробованих під час навчання інтерактивних вправ і технологій.

Ключові слова: майбутні логопеди, інтерактивні технології, інтеракції, професійна підготовка, мовленнєві порушення

\section{INTERACTIVE TECHNOLOGIES IN TRAINING FUTURE SPEECH THERAPISTS}

Abstract. It has been generalized in the article that vocational training of future speech therapists is based on mastering by students abilities in adjusting some components of impaired speech activity, which manifest themselves in the early stages of the child's development. The use of interactive technologies in training future therapists, who are called to master the abilities and skills in organization of optimal interpersonal interaction with children that have speech disorders, has been actualized.

The purpose of research is to reveal the possibilities of interactive technologies in training future speech therapists to work by specialty and ground the methods of using interactive exercises in speech therapists' work.

It has been established that for correctional and developmental work with children with severe speech disorders specialists, speech therapists can use interactive tasks. In the process of vocational training future speech therapists must try such interactive exercises, which they could use at the classes for children with speech disorders. Such tasks include exercises for articulatory gymnastics. The article provides examples of some interactions for teaching future speech therapists to work with children that have speech disorders. 
It has been proved that in vocational training of future speech therapists is necessary to orient students at elaboration of individual strategy of correcting speech disorders in the development of every child. With this purpose it is advisable to try some interactive exercises first, which future specialists can adapt for purposeful development of speech activity of a separate child, who has individual specific speech disorders, related to mental and physical changes in organism, problems with health that complicate social adaptation, study, development of children.

Thus, using interactive technologies in the process of vocational training future speech therapists aims to solve several important and interrelated tasks: direction of vocational education at a real practical activity of speech therapist that will promote growing the level of its competitiveness in the modern labor market; formation of abilities in using personally oriented approach to children with various speech problems; development of creativity in the creating individual strategies for organizing interactive interaction with children with speech disorders by adapting the exercises and technologies tested during study process.

Keywords: future speech therapists, interactive technologies, interactions, vocational training, speech disorders.

\section{ВСТУП}

Постановка проблеми. Професійна підготовка майбутніх логопедів у закладах вищої освіти базується на опануванні студентами вмінь корегувати окремі складники порушеної мовленнєвої діяльності, що проявляються здебільшого на ранніх етапах розвитку дитини. Окреслена проблема зумовлена «нерівномірністю проявів мовленнєвих порушень та різноманітністю особливостей розвитку психолінгвістичних ланок у кожної дитини» (Програма з корекційнорозвиткової роботи для підготовчого, 1-4 класів спеціальних загальноосвітніх навчальних закладів для дітей з тяжкими порушеннями мовлення («Корекція мовлення»), 2016, с. 4). Щоб певним чином виправити різнопланові мовленнєві порушення, які «проявляються в складних розладах (моторна, сенсорна та сенсомоторна алалії, афазія, заїкання, ринолалія, дизартрія, загальний недорозвиток мовлення, часто обтяжених уповільненим темпом та нерівномірністю розвитку психічних процесів» (Програма з корекційно-розвиткової роботи для підготовчого, 1-4 класів спеціальних загальноосвітніх навчальних закладів для дітей з тяжкими порушеннями мовлення («Корекція мовлення»), 2016, с. 5), майбутні логопеди покликані опанувати вміння і навички організації оптимальної міжособистісної взаємодії з учнямилогопатами, що уможливлюється в умовах використання інтерактивних технологій спочатку в період здобуття освіти за фахом, а надалі - у процесі професійної діяльності. Адже основою інтеракцій є посилена міжособистісна взаємодія, де логопед у роботі з дітьми із загальним недорозвитком мовлення (ЗНМ) може використовувати різні інтерактивні вправи, спрямовані на виправлення багатьох порушень у мовленнєвій системі дитини. При цьому майбутні логопеди покликані інтегрувати знання з психології (особливості розвитку дітей різного віку), медицини (інколи діти народжуються з діагнозами, які супроводжуються розладами мовлення, такими як дитячий церебральний параліч (ДЦП), спинна м'язева атрофія (СМА) та різні генетичні захворювання, при яких імовірна затримка психічного розвитку або розумова відсталість; хірургічне втручання при анатомо-фізіологічних дефектах мовленнєвого апарату (ринолалії чи короткій вуздечці)) [5]; виявляти знання сутності специфічних розладів писемного мовлення (дисграфія, дислексія, дизорфографія), порушення звукової сторони мовлення (дизартрія, ринолалія); ознайомлюватися 3 методикою адаптивної фізичної культури, що враховує аномальний розвиток фізичної і психічної сфери дитини тощо. Важливим науковим і практичним завданням у підготовці майбутніх логопедів є використання інтерактивних педагогічних технологій, які можуть використовуватися у подальшій роботі за фахом.

Аналіз останніх досліджень і публікацій, у яких започатковано розв'язання цієї проблеми, свідчить, що науковці присвячували праці проблемам корекційної педагогіки (В. Бондар, І. Єременко, М. Кот, С. Миронова, В. Синьов, О. Усанова, М. Ярмаченко та ін.), аналізували можливості педагогічної підтримки та соціальнопедагогічного супроводу учнів з особливими потребами в процесі здобуття середньої освіти (Колодная Н. А., 2011). Автори публікують результати своїх досліджень у галузі логопедії (О. Гопіченко, М. Савченко, В. Тарасун та ін.), акцентують увагу на важливості корекції мовленнєвих порушень у дітей з моторною алалією (Є. Соботович) та корекції вад читання (Е. Данілавічютє); особливостях мовленнєвого розвитку і компонентів мовленнєвої діяльності (В. Тищенко, М. Шеремет) та ін. Науковцями розроблено систему професійної компетентності вчителя-логопеда (Пінчук Ю.В., 2005). Дослідники пропонують використовувати інтерактивні ігри на логопедичних заняттях («нтерактивні ігри на логопедичних заняттях»). Проте проблему використання інтерактивних технологій у професійній підготовці майбутніх логопедів можна вважати недостатньо вивченою.

МЕТА І ЗАВДАННЯ ДОСЛІДЖЕННЯ - розкрити можливості інтерактивних технологій у підготовці майбутніх логопедів до роботи за фахом та обґрунтувати методику використання інтерактивних вправ у роботі логопедів.

\section{РЕЗУЛЬТАТИ ДОСЛІДЖЕННЯ}

Порушення різних аспектів мовленнєвої системи (фонетико-фонематичної, лексико-граматичної, зв'язного мовлення тощо) призводить до ускладнення процесу соціалізації учнів-логопатів, їх адаптації до шкільного середовища. Часто у таких учнів виникають проблеми у спілкуванні з однолітками, вчителями. Оскільки мовлення таких школярів нечітке, невиразне, малозрозуміле, знижується рівень міжособистісної взаємодії, що призводить до комунікативної ізоляції та зниження успішності школярів. Відтак у них поглиблюються і загострюються особистісні проблеми. Фахівці-логопеди покликані враховувати малорозвиненість мовленнєвої моторики таких дітей, позаяк «вади побудови артикуляційного апарату призводять до спотвореного артикулювання окремих звуків або їх груп. У дітей з порушенням центральної нервової системи спостерігається недостатня іннервація м'язів мовленнєвого апарату; звуковимова самостійно не вдосконалюється внаслідок того, що не формуються необхідні кінестезії, обмеженість словника, недосконалість граматичної будови, труднощі у формуванні і оформленні 
власних висловлювань» (Програма з корекційно-розвиткової роботи для підготовчого, 1-4 класів спеціальних загальноосвітніх навчальних закладів для дітей з тяжкими порушеннями мовлення («Корекція мовлення»), 2016, с. 5). Аналіз наукових публікацій засвідчує, що для корекційно-розвиткової роботи 3 дітьми 3 тяжкими порушеннями мовлення фахівцями розроблено спеціальні програми. Розробники такої програми зазначають, що проявом утруднень дитини в процесі оволодіння звуковим аналізом слова є неспроможність виділити заданий звук; виникають труднощі порівняння звукового складу слів, помилки під час відтворення звукового складу слова, навіть при правильній вимові ізольованих звуків (Програма з корекційно-розвиткової роботи для підготовчого, 1-4 класів спеціальних загальноосвітніх навчальних закладів для дітей з тяжкими порушеннями мовлення («Корекція мовлення»), с. 5). Тому, на нашу думку, майбутні логопеди в процесі професійної підготовки повинні апробувати такі інтерактивні вправи, які зможуть використовувати на заняттях з дітьми-логопатами.

3 метою підготовки майбутніх логопедів до розробки власної програми з використанням інтерактивних технологій у професійній діяльності доцільно, щоб студенти на заняттях апробували окремі інтерактивні вправи, визначили цільове призначення таких вправ, відчули на собі ефект від виконання спеціальних інтеракцій. До таких завдань відносимо вправи для артикуляційної гімнастики. Перед виконанням інтерактивних вправ увага студентів акцентується на їхній корисності: виконання завдань сприятиме покращенню кровопостачання артикуляторних органів, зміцненню м'язевої системи язика, губ, щік, збільшуватиме амплітуду рухів, зменшуватиме напруженість органів артикуляції (“Артикуляционная гимнастика”). Щоб переконатися у правильності виконання таких вправ, студенти групуються попарно, щоб візуально контролювати процес артикуляційної гімнастики один в одного.

Наведемо приклади окремих інтеракцій для навчання майбутніх логопедів роботи з дітьми-логопатами. Зауважимо, що навчальний ефект полягає не лише у правильному виконанні студентами запропонованих вправ, але й в обговоренні очікуваного результату і впливу на дитину.

Вправа 1. «Усмішка».

Завдання для виконання вправи: відобразити «білосніжну» усмішку (як у рекламі зубної пасти) і втримати її протягом 10 сек. Для створення ігрової інтерактивної ситуації під час виконанні такої вправи дітьми-логопатами доречно ілюструвати цей процес двома малюнками, які почергово демонструються: обличчя людини з такою усмішкою і без неї.

Питання для самоаналізу та обговорення: Які м'язи були найбільш напруженими? 3 якою метою логопед може використовувати таку вправу? Як можна вдосконалити зміст інтеракції для дітей різних вікових категорій?

Вправа 2. «Сопілочка».

Завдання для виконання вправи: витягнути губи для створення звуку «у» і проспівати його протягом 5-10 сек. У роботі з дітьми-логопатами можна використовувати справжню сопілку: тримаючи її на певній відстані від обличчя дитини, запропонувати дотягнутися до неї губами. Для ускладнення артикуляційної гімнастики доречно виконувати почергово вправи 1 і 2.

Питання для самоаналізу та обговорення: у чому полягає ефект почерговості виконання вправ 1 і 2? Яким чином можна захопити увагу дитини для виконання такої інтерактивної вправи?

Вправа 3. «Смаколики».

Завдання для виконання вправи: до краю нижньої і верхньої губи торкнутися паличкою з медом. Усміхнутися, привідкрити рот і широким язиком торкнутися краплини меду почергово знизу і зверху. Виконати вправу 5-10 разів.

Питання для самоаналізу та обговорення: 3 якою метою логопед може використовувати таку вправу? Яким чином можна активізувати дитину-логопата до виконання такої вправи?

Вправа 4. «Язик-стоматолог».

Завдання для виконання вправи: фіксувати язик протягом 5 сек. у таких положеннях: - між нижньою губою і нижніми зубами; - між верхньою губою і верхніми зубами;

- переміщувати язик так, ніби імітувати чищення зубів;

- впиратися язиком почергово в ліву і праву щоку, не відкриваючи при цьому рот; - «почистити» язиком верхні зуби з внутрішньої сторони; - «почистити» язиком нижні зуби з внутрішньої сторони; - порухати язиком біля верхніх альвеол.

Питання для самоаналізу та обговорення: Які труднощі виникали в процесі виконання такої вправи? Яка мета виконання такої вправи (наприклад, остання вправа спрямована на підйом язика для шиплячих). Яким чином можна ілюструвати таку вправу, щоб зацікавити дитину-логопата?

Набуває поширення використання спеціально розроблених логопедичних ігор, які можна віднести до інтерактивних технологій. Так, у мережі Інтернет пропонується логопедична розвивальна гра для дітей дошкільного та молодшого шкільного віку «Знайди зайвий предмет», призначена для проведення логопедичного онлайн заняття з теми «Узагальнення предметів». Ця логопедична гра відноситься до дидактичних матеріалів логопеда і створена для того, щоб займатися онлайн, не скачуючи її на свій комп'ютер. Нею можуть скористатися і батьки для цікавого й корисного проведення часу з дитиною. Логопедична гра проводиться дорослим, який переключає слайди, ставить запитання дитині. Якщо дитина не може відповісти на запитання, доречно сформулювати запитання, що наводять на правильну відповідь. Ігровий матеріал містить сім слайдів. На кожному з них після кліку мишкою включається анімація правильної відповіді («нтерактивні ігри на логопедичних заняттях»). 
Наведені приклади інтерактивних вправ, які майбутні логопеди можуть виконувати у роботі в парах чи самостійно, $€$ лише зразками завдань для дітей-логопатів. Зазвичай особистісно зорієнтована корекційна робота 3 такими дітьми потребує від фахівця-логопеда творчого підходу до організації індивідуальних занять. Тому в професійній підготовці майбутніх логопедів необхідно зорієнтовувати студентів на розробку індивідуальної стратегії корекції порушень мовлення в розвитку кожної дитини. 3 цією метою доцільно спочатку апробувати на заняттях окремі інтерактивні вправи, які майбутні фахівці можуть адаптувати для цілеспрямованого розвитку мовленнєвої діяльності окремо взятої дитини, яка має індивідуальні специфічні мовленнєві порушення, пов'язані з психофізичними змінами в організмі, проблемами здоров'я, які ускладнюють соціальну адаптацію, навчання, розвиток дітей.

На сучасному етапі розвитку інклюзивної освіти підготовка майбутніх логопедів передбачає їхню готовність до «проектування і коректування індивідуальної програми психофізичного розвитку дітей раннього віку з ризиком виникнення порушень мовлення, освіти і корекційної роботи на основі психолого-педагогічної, логопедичної діагностики дітей з обмеженими можливостями здоров'я» (Федорович Л. О., 2012, с. 288).

Водночас апробація оптимальних інтеракцій, які доцільно використовувати для реабілітаційної роботи 3 дітьми-логопатами, спонукатиме студентів до поглибленого вивчення специфіки психофізичного розвитку дітей, у яких можливе виникнення логопедичних проблем. Рефлексивний аналіз власної участі в моделях інтерактивної взаємодії на рівні «логопед - дитина» дає змогу майбутнім фахівцям виробити конкретну поетапну програму не лише для «консультування дітей раннього віку з ризиком виникнення порушень мовлення та обмеженими можливостями здоров'я», а й для «членів їх сімей і педагогів з проблем освіти, розвитку на основі комплексного підходу до реабілітаційного процесу» (Федорович Л. О., 2012, с. 288).

\section{ВИСНОВКИ ТА ПЕРСПЕКТИВИ ПОДАЛЬШИХ ДОСЛІДЖЕНЬ}

Отже, використання інтерактивних технологій в процесі професійної підготовки майбутніх логопедів розв'язує кілька важливих і взаємопов'язаних завдань: спрямованість професійної освіти на реальну практичну діяльність фахівця-логопеда, що сприятиме зростанню рівня його конкурентної спроможності на сучасному ринку праці; формування вмінь застосовувати особистісно зорієнтований підхід до дітей з різними логопедичними проблемами; розвиток креативності в розробці індивідуальних стратегій організації інтерактивної взаємодії з дітьми-логопатами шляхом адаптації апробованих під час навчання інтерактивних вправ і технологій.

Перспективи подальших досліджень вбачаємо в розробці взаємопов'язаного комплексу інтерактивних вправ, необхідних для формування спеціальних знань, умінь і навичок майбутніх фахівців, їх можуть використовувати у своїй професійній діяльності вчителі, реабілітологи, лікарі, логопеди, батьки та інші особи для роботи з дітьми, які мають порушення мовлення.

\section{СПИСОК ВИКОРИСТАНИХ ДЖЕРЕЛ}

Артикуляционная гимнастика. URL: https://logopedmaster.ru/index.php/blank-fvsw6

Інтерактивні ігри на логопедичних заняттях. URL: http://pedagogy.Inu.edu.ua/wp-content/uploads/2016/11

Колодная, Н. А. (2011) Социально-педагогическое сопровождение учащихся с ограниченными возможностями в процессе получения среднего образования. Вісник ЛнУ імені Тараса Шевченка, 14 (225). Ч. III, С. 62-70.

Пінчук, Ю.В. (2005) Система професійної компетентності вчителя-логопеда: (Автореф. дис. на здобуття наук. ступеня канд. пед.наук). Київ : НПУ ім. М.П. Драгоманова.

Правильне мовлення дитини: коли варто звертатись до логопеда. URL: http://tvoemisto.tv/news/pravylne_movlennya_dytyny_ koly_varto_zvertatys_do_logopeda_94311.html

Програма з корекційно-розвиткової роботи для підготовчого, 1-4 класів спеціальних загальноосвітніх навчальних закладів для дітей з тяжкими порушеннями мовлення («Корекція мовлення»). (2016) Київ, Міністерство освіти і науки України; Інститут спеціальної педагогіки НАПН України.

Федорович, Л. О. (2012) Концептуальні засади підготовки логопеда до роботи з дітьми раннього віку у вищих навчальних закладах в умовах інтеграції в Європейський освітній простір. Науковий часопис НПУ імені М. П. Драгоманова. Серія 19. Корекційна педагогіка та соціальна психологія, Вип. 21. С. 286-290.

\section{REFERENCES}

Artikuliatsionnaia. Retrived from: https://logopedmaster.ru/index.php/blank-fvsw6

Interaktyvni inry na lohopedychnykh zaniattiakh. Retrived from: http://pedagogy.Inu.edu. ua/wp-content/uploads/2016/11

Kolodnaia, N. A. (2011) Sotsialno-pedahohicheskoie soprovozhdenie uchashchikhsia s ohranichennymi vozmozhnostiami v protsesse polucheniia sredneho obrazovaniia Visnyk LNU imeni Tarasa Shevchenka. 14 (225). Ch. III. PP. 62-70.

Pinchuk, Yu. V. (2005) Systema profesiinoi kompetentnosti vchytelia-lohopeda.(Extended abstract of Candidate's thesis). Kyiv: NPU im. M. P. Drahomanova.

Pravylne movlennia dytyny: koly varto zvertatys do lohopeda Retrived from: http://tvoemisto.tv/news/pravylne_movlennya_dytyny_ koly_varto_zvertatys_do_logopeda_94311.html (in Ukrainian)

Prohrama z korektsiino-rozvytkovoi roboty dlia pidhotovchoho, 1-4 klasiv spetsialnykh zahalnoosvitnikh navchalnykh zakladiv dlia ditei z tiazhkymy porushenniamy movlennia ("Korektsiia movlennia") (2016). Kyiv.

Fedorovych, L. O. (2012) Kontseptualni zasady pidhotovky lohopeda do roboty z ditmy rannoho viku u vyshchykh navchalnykh zakladakh v umovakh intehratsii v Yevropeiskyi osvitnii prostir. Naukovyi chasopys imeni M. P. Drahomanova. Seriia 19. Korektsiina pedahohika ta sotsialna psykholohiia. Vyp. 21. PP. 286-290.

Статтю подано до редколегії 17.01 .2019 р.

Рекомендовано до друку 02.02.2019 p. 